\title{
CURRENT TRANSFORMATIONS OF EDUCATION - COOPERATIVE LEARNING STRATEGIES
}

\section{[SUCASNE PREMENY SKOLSTVA - KOOPERATIVNE VYUCBOVE STRATEGIE]}

\section{Zdenka Zastkova}

doi: 10.18355/PG.2019.8.2.9

\begin{abstract}
The aim of this paper is to justify the importance of implementing cooperative educational strategies into the educational process based on the theoretical reflection of education in the process of society transformation. In the paper we briefly analyze education and training from the perspective of educational discourses, we define and analyze cooperative learning as a possible strategy for the development of not only the cognitive but also the non-cognitive aspect of the pupil's personality.
\end{abstract}

\section{Key words}

theory of education and training, cooperative learning, principles of cooperative learning

\section{Anotácia}

Ciel'om príspevku je na základe teoretickej reflexie školstva v procese transformácie spoločnosti zdôvodnit' význam implementovania kooperatívnych edukačných stratégií do edukačného procesu. V príspevku stručne analyzujeme výchovu a vzdelávanie z pohl'adu pedagogických diskurzov, definujeme a analyzujeme kooperatívne učenie ako možnú stratégiu rozvoja nielen kognitívnej, ale aj nonkognitívnej stránky osobnosti žiaka.

\section{Kl'účové slová}

teórie výchovy a vzdelávania, kooperatívne učenie, princípy kooperatívneho učenia

\section{Úvod}

Vplyv globalizácie, postmoderny a neoliberalizmu významným spôsobom determinuje spoločenské prostredie a ovplyvňuje aj úvahy o tom, akú podobu by vzdelávanie malo mat' a akú rolu by malo plnit'. Je všeobecne známe, že výchova a vzdelávanie vždy reflektovali podmienky, potreby a očakávania spoločnosti. S vývojom a transformáciou spoločnosti sa v rôznych historických etapách kreovali aj diferencované predstavy o výchove a vzdelávaní, ktoré vytvárajú vlastný prístup k pomenovaniu a hodnoteniu edukačnej reality. Tieto prístupy často bývajú označené ako 
teórie, či koncepcie výchovy a vzdelávania. O. Kaščák a B. Pupala ${ }^{1}$ uvádzajú nasledovné prístupy ku výchove a vzdelávaniu, ktoré sa v posledných desat'ročiach $\mathrm{v}$ pedagogickej teórií a praxi významne presadili:

- Humanistický prístup - pozornost' orientuje na individualitu, na jej rozvoj a sebarozvoj v podmienkach podnetného prostredia, pričom v procese učenia dominuje zážitkovost' a osobná skúsenost' žiakov.

- Funkcionálny prístup - operuje s pojmom socializácia, zdôrazňuje, že človek sa stáva človekom osvojovaním si sociálnych noriem správania, adaptáciou na spoločenské prostredie. Dôraz sa kladie na sprostredkovanie žiadúcich noriem, disciplínu, predkladanie sociálnych vzorov správania, v dôsledku čoho sa má vytvorit' autonómia človeka.

- Interakčný prístup - snaží sa pomenovat' a opísat' procesy, v ktorých sa formuje humánnost' človeka a dochádza k rozvoju vy̌šśích psychických funkcií. $\mathrm{Na}$ základe interakcie vnútorných determinantov rozvoja s vonkajšími podnetmi sa podla tohto prístupu realizuje rozvoj a vývin človeka.

- Rekonštrukcionistický prístup - chápe školu ako spoločenskú inštitúciu viazanú na štruktúru spoločnosti, pričom výchovu prepája s deklarovanými sociálnymi a ekonomickými ohrozeniami a perspektívami. Vychádza z ideológií feminizmu, ekologizmu, či multikulturalizmu.

- Konsenzuálny prístup - $\mathrm{v}$ centre pozornosti dominuje koncept vzdelania, pretože ono formuje človeka vo svojej komplexnosti a l'udskosti. Vzdelanie je považované za fundament zabezpečenia kultúrnej stability hodnôt a medzigeneračnej kontinuity.

- Neoliberálny prístup - sa usiluje o formovanie aktívnej individuality (autonómneho subjektu v sieti ekonomických vzt’ahov stojacich na princípe konkurencie, sútaženia) pre pracovný trh. Podla tohto diskurzu si žiaci majú namiesto vedomostí osvojit' kompetencie uplatnitel'né najmä na trhu práce, ktoré budú funkčné pre budúcnost'. Ide napríklad o kompetencie flexibility, podnikavosti, pripravenosti na učenie, tvorivosti a pragmatickosti. Základným predpokladom vzdelávania je individualita, autonómia a slobodná vôl'a človeka, ktorý je sám za seba zodpovedný.

V súčasnosti badat' nejednoznačnost' názorov pedagogických odborníkov na to, aký diskurz by mala pedagogická realita zastávat', teda aké pedagogické myslenie by bolo najefektívnejšie. Na jednej strane sa zdôrazňujú preferencie výchovy (typické pre stále aktuálny humanistický diskurz), inde dominuje trend vzdelania alebo osvojovanie si akademickej spôsobilosti (najmä konsenzuálny a neoliberálny prístup), alebo sa zdôrazňuje pragmatickost' vzdelania pre potreby spoločnosti, ktorej ústredným pojmom je socializácia (predovšetkým funkcionálny prístup). Aký charakter má teda výchova a vzdelávanie mat', aby zodpovedali súčasným trendom? Ak uvažujeme

\footnotetext{
${ }^{1}$ KAŠC̆AK, O., PUPALA, B. 2009. Výchova a vzdelávanie v základných diskurzoch. Prešov : Rokus. s. $18-29$.
} 
v intenciách dynamiky edukačného procesu, pri hl'adaní odpovede si pomôžeme názorom E. Petláka ${ }^{2}$, ktorý z hl'adiska budúceho vzdelávania apeluje na potrebu školy zohl'adňovat' rozvoj v týchto oblastiach:

- humanizácia - zabezpečit' všestranný rozvoj osobnosti prostredníctvom metód, ktoré budú voči jedincovi humánne a pripravia ho na začlenenie do spoločnosti podla jeho možností a schopností,

- integrácia - predovšetkým sa týka obsahu vzdelávania,

- globalizácia - pripravenost' človeka nielen pre tú - ktorú krajinu alebo oblast', ale človeka flexibilného, výkonného, tvorivého uplatnitel'ného v ktorejkol'vek krajine,

- $\quad$ spolupráca a kooperácia - potreba prípravy žiakov na spoluprácu a kooperáciu,

- $\quad$ mobilita - príprava žiakov na život v meniacom sa svete, adaptácia a flexibilita na meniace sa požiadavky, rekvalifikácia potrebná pre udržanie sa na trhu práce a pod.,

- sústavnost' vzdelávania - príprava na budúce samovzdelávanie, učenie metódam samoučenia...

Podobne sa snažila vymedzit' požiadavky na to, aká by mala výchova a vzdelávanie pre potreby 21 . storočia byt' aj Medzinárodná komisia $\mathrm{UNESCO}^{3}$, ktorá sformulovala 4 piliere výchovy a vzdelávania:

1. Učit' sa poznávat' - ovládat' nástroje, prostredníctvom ktorých možno bádat', skúmat', chápat' nové a po celý život sa rozvíjat', pretože za skutočný poznatok sa považuje ten, ku ktorému človek dospeje sám.

2. Učit' sa konat' - vyrovnávat' sa s rôznymi sociálnymi a pracovnými situáciami, pracovat' $\mathrm{v}$ tímoch, byt' aktívnym riešitel'om životných situácií schopným slobodného rozhodovania a nie manipulovaným pasívnym objektom.

3. Učit' sa žit' spoločne - vážit' si iných, tolerovat' a rešpektovat' odlišnost' druhých, kooperovat' s nimi, nechciet' ich ovládat' a súperit' s nimi, ale konat' voči nim zodpovedne a mravne.

4. Učit' sa byt' - existovat' ako autentická osobnost', ktorá vie čo chce, riadi si vlastný život, nachádza $\mathrm{v}$ ňom zmysel, vlastné št'astie a identitu.

Na podnet transformácie školstva na základe Národného projektu Milénium a Zákonom č. 245/2008 Z. z o výchove a vzdelávaní (školský zákon) a o zmene a doplnení niektorých zákonov bolo vypracovaných niekol'ko

\footnotetext{
${ }^{2}$ PETLÁK, E. 2012. Inovácie v edukačnom procese. Dubnica nad Váhom : Dubnický technologický inštitút. s. $15-17$.

3 In SUCHOŽOVÁ, E. 2014. Rozvíjanie a hodnotenie klúčových kompetencii v edukačnom procese. MPC. s. 14.

Slavonic Pedagogical Studies Journal, eISSN 1339-9055, ISSN 1339-8660, Volume 8 Issue 2, 2019
} 
odporučení, ktorými kompetenciami by mal moderný človek disponovat'. $Z$ vyššie uvedeného okrem iných vyplýva aj potreba prípravy jedinca zameraného na spoluprácu, kooperáciu. Práve schopnost' kooperovat' sa nám javí ako aktuálna výzva a potreba. S. Kose ${ }^{4}$ uvádza, že spolupracujúci l'udia sú opísaní ako empatickí, tolerantní, súcitní, nápomocní, spravodliví jednotlivci, ktorí radi využívajú pomoc ostatných a pokúšajú sa spolupracovat's ostatnými čo najviac.

David a Roger Johnsonovci ${ }^{5}$ uvádzajú 4 najdôležitejšie výzvy 21. storočia, v ktorých práve spolupráca zohráva ústrednú úlohu:

1. rýchlo rastúca globálna závislost', ktorá sa prejaví v miestnej rozmanitosti a povedie $\mathrm{k}$ častejším a intenzívnejším konfliktom,

2. zvyšujúci sa počet demokracií na celom svete,

3. potreba tvorivých podnikatel'ov,

4. rastúci význam medziludských vzt’ahov, ktoré ovplyvňujú rozvoj osobnej identity.

Následne uvádzajú, že kooperatívne učenie je jedným z nástrojov vzdelávania, ako týmto výzvam čelit', pretože umožňuje rozvoj takých kompetencií, ktoré sú potrebné pre riadenie spolupráce na globálnej úrovni $\mathrm{v}$ takej miere, ako aj na individuálnej a spoločenskej úrovni.

Kooperatívne učenie podl'a Slavina ${ }^{6}$ možno charakterizovat' ako učenie, ktoré nastáva počas uplatňovania takých metód, v rámci ktorých deti pacujú v malých skupinách, aby si navzájom pomáhali učit' sa. Podl’a D. W. Johnsona a R. T. Johnsona ${ }^{7}$ ide o riadené využitie malých skupín tak, aby žiaci pracovali spoločne pri maximalizácií ich vlastného učenia a učenia sa navzájom. V rámci kooperatívnych situácií sa jednotlivci snažia dosiahnut' výsledky, ktoré prinášajú výhody im samotným, ale aj ostatným členom skupiny. T. Jablonský ${ }^{8}$ uvádza, že kooperatívna forma učenia je vhodná pre triedy, ktoré pozostávajú zo žiakov s rôznymi úrovňami kognitívnych spôsobilostí, pretože všetci členovia tímu sú potrební na splnenie úlohy a každý má príležitost' zapojit' sa. Práve $\mathrm{v}$ dnešnej dobe, ked' do škôl prichádzajú žiaci z rôznych etnických, kultúrnych a sociálno ekonomických prostredí, sa nám javí kooperatívne učenie nanajvýš vhodné, pretože umožňuje rešpektovat' a využívat' skúsenosti detí z rôznych prostredí a stavat' na nich v prospech rozvoja všetkých zainteresovaných.

\footnotetext{
${ }^{4}$ KOSE, S. 2003. Psychobiological Model of Temperament and Character : TCI. In Yeni Syposium, vol. 41, s 92.

${ }^{5}$ JOHNSON, D. W., JOHNSON, R. T. 2014. Cooperative Learning in 21st Century. In Anales de Psycologia, vol. 30, s. 841.

${ }^{6}$ SLAVIN, R. E. 2008. Cooperative Learning, Succes for All, and Evidence - based Reform in education. In Éducation et didactique, vol. 2, s. 152.

${ }^{7}$ JOHNSON, D. W., JOHNSON, R. T. 2010. The Impact of Cooperative, Competitive, and Individualistic Learning Environments on Academic Achievement. s. 2.

${ }^{8}$ JABLONSKÝ, T. 2006. Moderné trendy vo výučbe - Kooperatívny spôsob výučby 2. Ružomberok: Edičné stredisko pedagogickej fakulty v Ružomberku. s. 30.
} 
Takisto je táto stratégia vyučovania vhodná pre školy, ktoré v 21. storočí predstavujú prostredie podl'a H. Kasíkovej ${ }^{9}$ :

- interaktívne - s väzbami vo vnútri systému i smerom von (k rodičovskej a širšej verejnosti),

- $\quad$ inkluzívne - na úrovni bezbariérového prístupu do škôl i v rámci kurikula, dôraz na rovnost' príležitostí a právo každého vzdelávat' sa v podmienkach bežných škôl,

- interdisciplinárne - zdôrazňuje vzt'ahy medzi jednotlivými oblast'ami poznania,

- internacionálne - vyzývajúce k širokému kontextu uvažovania o všel'udských hodnotách,

- interpersonálne - budujúce poznanie na sociálnych vzt'ahoch, ktoré napomáhajú spoločnosti.

Z uvedeného vyplýva, že kooperatívne učenie ako možná stratégia výchovy a vzdelávania reaguje na potreby a výzvy zameranosti školstva 21. storočia, v zmysle učit' sa poznávat', učit' sa konat', učit' sa žit' spoločne a učit' sa byt'. Ide o takú stratégiu vzdelávania, ktorá umožňuje zámerne využívat' usporiadanie sociálnych vzt'ahov v triede, ktoré môžu ovplyvnit' nielen samotný proces učenia, ale aj jeho výsledky. Vychádza z predpokladu, že sociálne vzt'ahy, najmä miera interakcie medzi učitel'om a žiakmi a predovšetkým žiakmi navzájom, sú podstatným prvkom v socializácií jednotlivca a v jeho kognitívnom, sociálnom a mravnom vývine. D. W. Johnson a R. T. Johnson ${ }^{10}$ poukazujú vo vyučovaní na tri spôsoby usporiadania sociálnych vzt'ahov: kompetitívne (sút'aživé), kooperatívne a individualistické. Tieto tri väzby sa líšia spôsobom participácie, profitu a úspechu pri dosahovaní ciel'a. H. Kasíková ${ }^{11}$ hovorí pri spolupráci o tzv. pozitívnej vzájomnej závislosti l’udí. Znemená to, to, že pri dosahovaní ciel'a sú l’udia na sebe vzájomne závislí, úspech jednotlivca je determinovaný úspechom druhých a naopak, skupina má prospech $\mathrm{z}$ činnosti jednotlivca, teda profitujú všetci zúčastnení. V porovnaní s kooperatívnym správaním pri kompetitívnom ide o úsilie jednotlivca dosiahnut' ciel' na úkor iných. D. W. Johnson a R. T. Johnson ${ }^{12}$ uvádzajú, že kooperatívne učenie ponúka priestor pre produktívne využitie kompetitívneho a individualistického učenia, pretože je práve taká forma

\footnotetext{
${ }^{9}$ KASÍKOVÁ, H. 2016. Kooperativní učení, kooperativní škola. Portál : Praha. s. 33. ${ }^{10}$ JOHNSON, D. W., JOHNSON, R. T. 2010. The Impact of Cooperative, Competitive, and Individualistic Learning Environments on Academic Achievement. s. 2.

${ }^{11}$ KASÍKOVÁ, H. 2009. Učíme se spolupráci. Kladno : AISIS. s. 11.

12 JOHNSON, D. W., JOHNSON, R. T. 2014. Cooperative Learning in 21st Century. In Anales de Psycologia, vol. 30, s. 841.
} 
vyučovania, ktorá umožňuje všetkým žiakom spolupracovat' s ostatnými, sútažit' pre zábavu a radost' a učí ich učit' sa pre seba samotných.

Podla zamerania činnosti uvádza M. Zelina ${ }^{13}$ nasledovné zloženie učiacich sa skupín v kooperatívnom učení:

- žiacky tím - učitel' prezentuje učivo, iniciuje problém a skupina žiakov $(4-5)$ sa spolu učí, riešia problém,

- hráčsky tím - podobne ako v žiackom tíme, pričom skupiny sa medzi sebou hrajú, sút'ažia,

- vyučovací tím - každý člen skupiny dostane inštrukciu, ktoré učivo má naučit' ostatných členov skupiny, prípadne sa žiaci učia učivo $\mathrm{z}$ informačných zdrojov, a následne učivo prebrat' spolu a preskúšat' sa,

- spoločne učiaci sa tím - žiaci riešia problém, pričom majú diferencované role, napr. jeden vymýšl’a, druhý je precízny, d’alší oponuje, iný hodnotí dianie v tíme a podobne,

- vyšetrovací tím - skupina komplexne vyšetruje problém podl'a nejakej heuristickej schémy, potom pred ostatnými skupinami podáva správu o postupe a realizácii riešenia problému.

Je zrejmé, že kooperatívne učenie umožňuje zámerne vytvárat' konštruktívne didaktické situácie, ktoré následne prinášajú mnohé efekty. Z hladiska usporiadania vzájomných sociálnych vzt’ahov a následným rozvojom osobnosti ich analyzovala H. Kasíková ${ }^{14}$ :

- Deti sa vinterakcií s vrstovníkmi učia napodobňovaním a interiorizáciou postojom, hodnotám, zručnostiam a vedomostiam, ktoré nemôžu získat' od dospelých.

- Interakcia s vrstovníkmi poskytuje modely prosociálneho správania a jeho podporu, hlavne schopnost' podelit' sa, darovat', pomôct', starat' sa, zdiel'at'.

- Vrstovníci poskytujú modely, ako sa učit' kontrole bezprostredných impulzov a potrieb, učia sa čakat'.

- $\quad$ Učí sa pozerat' sa na problém s perspektívy iných, nielen zo svojho uhla pohladu.

- Vrstovnícke vzt’ahy majú silný vplyv na vývoj hodnôt a sociálnej senzitivity nutnej pre autonómiu osobnosti. Žiaci sa učia zosúladit’ očakávania iných s vlastnými rozhodnutiami.

- Deti si uvedomujú podobnosti a odlišnosti medzi sebou a ostatnými, konfrontujú sa so sociálnymi rolami a tým si formujú vlastnú identitu prostredníctvom integrácie hodnôt a postojov.

\footnotetext{
${ }^{13}$ ZELINA, M. 2010. Teórie výchovy alebo hladanie dobra. Bratislava : SPN. s. 182.

${ }^{14}$ KASÍKOVÁ, H. 2016. Kooperativní učení, kooperativní škola. Portál : Praha. s. 36.
} 
- Priaznivá priatel'ská atmosféra pomáha $\mathrm{k}$ udržaniu psychického zdravia členov skupiny.

- Spolupráca vo vzájomných vzt’ahoch prispieva k motivácií $\mathrm{k}$ činnosti, čo sa prejavuje vyšším výkonom žiakov.

Ďalšie výhody uvádzajú napríklad T. Jablonský ${ }^{15}$, E. Petlák ${ }^{16}$ a H. Kasíková $^{17}$ nasledovne: rozvíja sociálne kontakty žiakov, pôsobí na intelektuálny rozvoj, prispieva $\mathrm{k}$ vytváraniu návykov na spoločnú prácu, získané vedomosti sú trvácnejšie, pretože žiaci sa $\mathrm{k}$ nim dopracovali vlastnou aktivitou, učí sa demokratickému rozhodovaniu, rozvíja samostatnost', tvorivost', podporuje sebadôveru žiaka, klesá počet izolovaných a neoblúbených žiakov, vyjadrovanie je prirodzenejšie, žiaci preberajú zodpovednost' za učenie vrátane chýb, sú viac motivovaný pre činnost', žiaci sa učia organizovat' prácu, kooperatívne činnosti privádzajú žiakov k utváraniu vzájomných vzt’ahov, v ktorých sa budú neskoršie v skutočnej práci a v živote nachádzat'... Za problematické stránky kooperatívneho učenia podl'a spomínaných autorov môžeme považovat': niektorí žiaci zostávajú pasívni, nezdravé súperenie a ctižiadostivost' niektorých skupín, problém organizovania si práce v skupine, prevaha aktivity najlepších žiakov, problém objektívneho hodnotenia podielu žiakov na práci v skupine, hlučnost' skupín, v procese učenia môžu vznikat' chyby, ktoré sa ihned' nekorigujú, problém hodnotenia učebnej činnosti, náročnejšia príprava učitela, slabá práca a neúspechy jednotlivcov sa maskujú a zahal'ujú do anonymity. Ak sú však rešpektované základné princípy kooperatívneho učenia, problémové stránky sa dajú eliminovat', čo však súvisí s dostatkom pedagogického taktu a skúsenost’ami učitel’a s touto organizačnou formou vyučovania. Učitel' tu pôsobí ako facilitátor, ktorý prácu žiakom navodí, ul'ahčuje ju, inštruuje.

Aby bolo kooperatívne učenie efektívnejšie ako individualistické, kompetitívne a tradičné, aby došlo k žiaducemu pokroku v učení sa žiakov, musí byt' dodržaných 5 základných princípov ${ }^{18}$ :

1. jasne vnímaná pozitívna vzájomná závislost' - splnenie úlohy možno dosiahnut' len spoločným úsilím, preto žiaci koordinujú svoje úsilie s úsilím ostatných,

${ }^{15}$ JABLONSKÝ, T. 2006. Kooperatívne učenie vo výchove. Trnava : MTM Levoča. s. 45.

${ }^{16}$ PETLÁK, E. 2012. Inovácie v edukačnom procese. Dubnica nad Váhom : Dubnický technologický inštitút. s. 135.

${ }^{17}$ KASÍKOVÁ, H. 2016. Kooperativni učení, kooperativní škola. Portál : Praha. s. 19.

${ }^{18}$ JOHNSON, D. W., JOHNSON, R. T. 2009. An Educational Psychology Success Story: Social Interdependence Theory and Cooperative Learning. In Educational Researcher, vol. 38, s. $366-370$.

Slavonic Pedagogical Studies Journal, eISSN 1339-9055, ISSN 1339-8660, Volume 8 Issue 2, 2019 
2. interakcia tvárou $\mathrm{v}$ tvár - podporuje komunikáciu, kooperáciu a sociálne vzt’ahy,

3. jasne vnímaná individuálna zodpovednost' - úsilie žiaka má význam a zmysel pre celú skupinu, kooperatívna práca spätne „posilňuje“ žiaka,

4. sociálne zručnosti - v rámci procesu naučit' deti spolupracovat' sa žiaci učia vzájomnej dôvere, akceptovaniu, komunikácii, konštruktívnemu riešeniu konfliktov atd',

5. reflexia skupinovej činnosti - efektívnost' spoločnej činnosti je závislá od toho, ako skupina reflektuje svoju prácu a stanovuje si d’alší postup.

Pre porovnanie uvádzame aj členenie podl’a Y. Bertranda ${ }^{19}$, ktorý považuje za základné princípy kooperatívneho učenia nasledovné:

1. Partnerstvo - žiaci si rýchlejšie a kvalitnejšie osvojujú obsah učiva, ak spoločne pracujú na jednom projekte. Sútaživost' je nahradená partnerstvom.

2. Pružnost' - kooperatívne učenie sa prispôsobuje potrebám skupín žiakov, kultúre regiónov, okolnostiam vyučovania uplatnením rôznorodých spôsobov realizácie.

3. Vzájomná pomoc - všetci si vzájomne pomáhajú a spolupráca je prínosom pre každého žiaka.

4. Kognitívna zložitost' - žiak sa dostáva do rôznych kognitívnych, psychologických a sociálnych situácií, kde vystupuje mnoho premenných, učí sa reagovat'.

5. Rozmanitost' sociálnych situácií - vyučovanie vedie k osvojeniu si hodnotných vzorcov sociálneho správania a k eliminácii negatívnych (napr. sút'aživost', rasizmus).

6. Zlepšenie sebahodnotenia - úspešná práca skupiny učí vnímat' pozitívne i samotných jedincov, nadobúdajú pocit dôvery, v prípade potreby dokážu požiadat’ o pomoc, čo je pre žiakov motivujúce.

Uvedené princípy argumentujú mnohé efekty implementácie kooperatívneho učenia do edukačného procesu. Prejavujú sa v kognitívnej, afektívnej i sociálnej oblasti. Zmysel kooperatívneho učenia výstižne pomenovala $\mathrm{H}$. Kasíková ${ }^{20}$ ako mnohostranný rozvoj jedinca v učiacom sa spoločenstve. Otázka implementácie kooperatívneho učenia ako možnej stratégie výchovy a vzdelávania je $\mathrm{v}$ súčasnej pedagogickej teórii mnoho diskutovaný proces (najmä $\mathrm{v}$ súvislosti $\mathrm{s}$ inkluzívnym vzdelávaním, inovatívnymi vyučovacími postupmi, prevenciou sociálno - patologických

\footnotetext{
${ }^{19}$ BERTRAND, Y. 1998. Soudobé teorie vzdélávaní. Praha: Potrál. s. $141-151$.

${ }^{20}$ KASÍKOVA, H. 2007. Kooperativni učení a vyučování - Teoretické a praktické problémy. Praha: Karolinum. s. 87.
} 
javov atd'.), avšak v praxi málo uplatňovaný. Teoretické východiská tejto koncepcie do našich podmienok prenikajú hlavne zo zahraničných krajín (USA, Kanady), kde je tejto oblasti venovaná značná pozornost' nielen na úrovni teoretickej rozpracovanosti problematiky, ale i na úrovni rôznych empirických výskumov a implementácie konkrétnych metodík. Na území Českej a Slovenskej republiky táto problematika hl’adá svoje zázemie najmä v prácach Hany Kasíkovej, Dagmar Sitnej a Tomáša Jablonského, ktorí nezostávajú len pri teoretickom rozpracovaní uvedenej problematiky, ale snažia sa o jej implementáciu do prostredia škôl v podobe dostupných metodík, obsahujúcich námety pre hry a činnosti vedúce $\mathrm{k}$ väčšej spolupráci. Jedná sa napríklad o publikáciu H. Kasíkovej - Kooperatívní učení, kooperativní škola (Portál, 2016), D. Sitnej - Metody aktivního vyučování, spolupráce žáků ve skupinách (Portál, 2013), T. Jablonského Moderné trendy vo výučbe - Kooperatívny spôsob výučby (PF KU v Ružomberku, 2006). Sme toho názoru, že či už škola bude pripravovat' žiakov pre dosahovanie dobrých výsledkov akademickej vzdelanosti, alebo sa bude orientovat' na rozvíjanie pozitívnych medzil'udských vztahov, kooperatívne učenie môže nájst' svoje zastúpenie v edukačnom procese ako vhodná organizačná forma výchovy a vzdelávania integrujúca preferencie rôznych diskurzov. Práve táto koncepcia otvára priestor pre zvýšenie efektívnosti edukačného procesu tým, žiaci sa učia informácie a zároveň sa adaptujú na podmienky prostredia, čiže formujú sa v zmysle sebaúcty, sebaaktualizácie a sebavýchovy, čo determinuje následnú úspešnost' žiakov $\mathrm{z}$ aspektu budúcnosti.

\section{Bibliographic references}

BERTRAND, Y. 1998. Soudobe teorie vzdelavani. Praha: Potral. ISBN 97880-7178-216-2.

JABLONSKY, T. 2006. Moderne trendy vo vyucbe - Kooperativny sposob vyucby 2. Ruzomberok: Edicne stredisko pedagogickej fakulty $\mathrm{v}$ Ruzomberku. ISBN 80-8084-074-1.

JABLONSKY, T. 2006. Kooperativne ucenie vo vychove. Trnava: MTM Levoca. ISBN 80-89187-13-7.

JOHNSON, D. W. - JOHNSON, R. T. 2014. Cooperative Learning in 21st Century. In Anales de Psycologia, vol. 30, pp. $841-851$.

JOHNSON, D. W. - JOHNSON, R. T. 2010. The Impact of Cooperative, Competitive, and Individualistic Learning Environments on Academic Achievement. [online]. [Cit. 04.03.2019]. Available online:

https://www.researchgate.net/publication/260596923_Johnson_D_W_Johnso n_R_T_2013_The_impact_of_cooperative_competitive_and_individualistic_ learning_environments_on_achievement_In_J_Hattie_E_Anderman_Eds_Int ernational_handbook_of_student_achievement_372 
JOHNSON, D. W. - JOHNSON, R. T. 2009. An Educational Psychology Success Story: Social Interdependence Theory and Cooperative Learning. In Educational Researcher, vol. 38, pp. 365 - 379.

KASIKOVA, H. 2009. Ucime (se) spolupraci. Kladno: AISIS. ISBN 978-80904071-6-9.

KASIKOVA, H. 2016. Kooperativni uceni, kooperativni skola. Portal: Praha. ISBN 978-80-262-0983-6.

KASCAK, O. - PUPALA, B. 2009. Vychova a vzdelavanie v zakladnych diskurzoch. Presov: Rokus. ISBN 978-80-89055-98-2.

KOSE, S. 2003. Psychobiological Model of Temperament and Character : TCI. In Yeni Syposium, vol. 41, pp. 86 - 97. [online]. [Cit. 09.03.2019]. Available online:

https://www.researchgate.net/publication/26390766_A_Psychobiological_M odel_of_Temperament_and_Character_TCI

SITNA, D. 2013. Metody aktivniho vyucovani, spoluprace zaku ve skupinach. Praha: Portal. ISBN 978-80-262-0404-6.

SLAVIN, R. E. 2008. Cooperative Learning, Succes for All, and Evidence based Reform in education. In Education et didactique, vol. 2, pp. $151-159$. ISSN $2111-4838$.

SUCHOZOVA, E. 2014. Rozvijanie a hodnotenie klucovych kompetencii v edukacnom procese. MPC. ISBN 978-80-8052-857-7.

PETLAK, E. 2012. Inovacie v edukacnom procese. Dubnica nad Vahom: Dubnicky technologicky institut. ISBN 978-80-89400-39-3.

ZELINA, M. 2010. Teorie vychovy alebo hladanie dobra. Bratislava: SPN. ISBN 978-80-10-01884-0.

Mgr. Zdenka Zastková

Department of Preschool and Elementary Education.

Catholic University in Ruzomberok

Hrabovská cesta 1A

03401 Ružomberok

Slovakia

z.senciova@gmail.com 